\title{
Un estudio socioeducativo sobre la evaluación del crecimiento económico en países seleccionados
}

\section{A socio-educational study on the evaluation of economic growth in selected countries}

\author{
Mehmet Çanakc1 ${ }^{1}$ \\ Inonu University, Malatya, Turkey ${ }^{1}$
}

Orcid ID: https://orcid.org/0000-0002-3878-562X ${ }^{1}$

Recibido: 12 de enero de 2021

Aceptado: 30 de junio de 2021

\begin{abstract}
The agricultural sector, which has a wide range of economic and social effects, it has a strategic importance due to national income, employment, consumption expenditures, raw material supply to other sectors and its share in exports. In this context, this paper revisits the debate on the role of agriculture in promoting economic growth in a selection of selected agricultural countries. This study analyzes the links between agriculture variables and gross domestic product growth with the help of cointegration test, Autoregressive Distributed Lag Limit Test (ARDL) approach for the relevant period, Augmented Dicky Fuller (ADF) and PP test (PMG). The results show that the sustainable increase in agricultural income positively changes national income and is the driving force of growth; strong evidence was found showing that the increase in the agricultural workforce decreases the national income in the long term. This strong evidence supports the agro-growth hypothesis that shows that; in recent years, discussions on the relationship between the concept of sustainable growth and agricultural policy have become more prominent. For this reason, it is recommended that more and more countries contribute to solving economic growth problems by following and applying agricultural productivity methods.
\end{abstract}

Keywords: Agriculture Policies, Agricultural employment, Economic Growth, Panel ARDL, social study.

\section{Resumen}

El sector agrícola, que tiene una amplia gama de efectos económicos y sociales, tiene una importancia estratégica debido a la renta nacional, el empleo, los gastos de consumo, el suministro de materias primas a otros sectores y su participación en las exportaciones. En este contexto, este documento revisa el debate sobre el papel de la agricultura en la promoción del crecimiento económico en una selección de países agrícolas seleccionados. Este estudio analiza los vínculos entre las variables agrícolas y el crecimiento del producto interno bruto con la ayuda de la prueba de cointegración, el enfoque Autoregressive Distributed Lag Limit 
Test (ARDL) para el período relevante, Augmented Dicky Fuller (ADF) y PP test (PMG). Los resultados muestran que el aumento sostenible de la renta agrícola cambia positivamente la renta nacional y es la fuerza impulsora del crecimiento; Se encontraron pruebas contundentes que muestran que el aumento de la mano de obra agrícola disminuye el ingreso nacional a largo plazo. Esta fuerte evidencia apoya la hipótesis de crecimiento agrícola que muestra que; En los últimos años, las discusiones sobre la relación entre el concepto de crecimiento sostenible y la política agrícola se han vuelto más prominentes. Por ello, se recomienda que cada vez más países contribuyan a resolver los problemas del crecimiento económico siguiendo y aplicando métodos de productividad agrícola.

Palabras clave: Políticas agrarias, empleo agrario, crecimiento económico, panel ARDL, estudio social.

\section{Introduction}

The COVID-19 outbreak is expected to affect agricultural markets over the next 15 years. The continuation of lower economic growth compared to the previous year's affects the income sources of the farmers, especially food security, and makes the agricultural sector more vulnerable with the negative effects of the climate change that has been going on for a long time (Pulighe \& Lupia, 2020). With the effect of the global epidemic, the size of this fragile structure, i.e., the depth, will increase the value of field crops with the decline in national income. Even agricultural products are expected to become as valuable as gold (Nie et al., 2020).

In 2020, the Covid-19 outbreak highlighted the sensitivity of supply chains, the potential consequences of countries' external dependence, and the importance of being a self-sufficient country. However, there are also issues that have priority over the breakdown of the supply chain in the causes of the possible global food crisis (Elleby et al., 2020). In her TED speech in 2017, Menker said in the research of Gro Intelligence Company that the important breaking point for food security will be realized in 2027 , not 2050 as the rest of the world thought. For this reason, when we look at the agricultural world, with the joint effect of rapid economic growth and population increases, the world economy may face a calorie deficit that it cannot met. Measuring food in kilograms, on the other hand, causes countries to make calculations on a kilogram basis while determining their policies, and in fact neglect calculations based on daily calorie intake and nutritional value that change over time (Cobre et al., 2021). Therefore, one of the most important instruments for ending extreme poverty, rising mutual prosperity and feeding an estimated 9.7 billion people by 2050 is agricultural production (Dhahri \& Omri, 2020). 
For the other hand, development in the agricultural sector is two to four times more successful compared to other sectors in increasing the income of the poorest. In 2016, research showed that $65 \%$ of poor working adults gained their living from agriculture (Castaneda et al. 2016). Agriculture is also important to economic growth: in 2018 it accounted for $4 \%$ of the global gross domestic product (GDP) and in some developing countries it may account for more than 25\% of GDP (Havemann et al., 2020). If we will look at these developments performance in the agricultural sector in Turkey respect it can easily be said that Turkey is implementing malpractices in the agricultural sector and they are blind on the oncoming agricultural crisis. In Turkey agriculture sector is inefficient because of mistakes in both production and exports marketing hence huge need for innovation (COMCEC, 2018). Turkey Exporters Assembly (TIM) Agriculture report (2016) includes the new and old approach for on agriculture. Turkey, although with more land suitable for agricultural productivity as compared to other countries, lagging behind in many of these countries because of limiting agriculture to the old-fashioned basic farmer activities (Yesilcinar \& Cetin, 2005). It is necessary to adopt a new understanding, which defends that agriculture is a production and distribution system, where farmers and marketers are partners, not competitors. If this new approach also provided other requirements will be reduced and productivity issues in agriculture in Turkey will increase agriculture's economic contribution.

\section{The case of Turkey and Europe}

In Turkey, agriculture constitutes 6\% of GDP and the agricultural sector employs 19\% of the workforce (Yeni \& Teoman, 2020). For this reason, it is one of the most important sectors of the Turkey's economy. Thanks to its suitable climate conditions and soil, Turkey is coming forefront from the agricultural aspects. However, the research and the data collected underlines that production efficiency is very low and hard to break the barriers in mind on the modern agricultures. Although the agricultural employment is over $20 \%$, it shows that the number of products and income obtained is relatively low, due to wrong agricultural practices and marketing methods (Pelek, 2019). According to the data of the Food and Agriculture Organization of the United Nations (FAO), the production per hectare by country in wheat yield are as table 1 and table 2. 
Table 1

Productivity rates in wheat production by country (2019)

\begin{tabular}{lc}
\hline Countries & Wheat ton/hectare \\
\hline Netherlands & 9.2 \\
Germany & 8.6 \\
France & 7.3 \\
Italy & 3.8 \\
Turkey & 2.4 \\
\hline
\end{tabular}

Source: FAO, 2021

Table 2

Country-based wheat production (2019)

\begin{tabular}{lll}
\hline Countries & $\begin{array}{l}\text { Hectare } \\
\text { (million) }\end{array}$ & $\begin{array}{l}\text { Production (million } \\
\text { ton) }\end{array}$ \\
\hline Turkey & 7.8 & 19.0 \\
Germany & 3.2 & 27.8 \\
France & 5.3 & 38.9 \\
\hline
\end{tabular}

Source: FAO, 2021

As can be seen in Table 1, the Netherlands is at the top with a rate of 9.2. The Netherlands also ranks second in the world after the USA with its share of imports in agriculture and also ranks second in the world after the USA in terms of agricultural products export. On the one hand, it is a country with vast fertile agricultural lands that covers half of the North American continent, on the other hand, it is a small country that has a significant part of the agricultural lands squeezed into the western end of Europe and sees the sun in a few parts of the year (Arnold et al., 2019).

Considering that the Netherlands is smaller than the USA in terms of land area, these data are undoubtedly more meaningful and impressive (Liu et al., 2014). Table 2 reveals that the efficiency is about 3 times more than Germany to Turkey. We can say that this is due to the use of high-quality seeds, which is one of the most important factors in wheat productivity. While the area where wheat is produced is very high on a hectare basis, it is obvious that the amount of wheat produced is not relatively high compared to other countries (Arnold et al., 
2019). While this is the case in wheat production, we may continue our analysis over the data of different agricultural products.

According to FAO data, orange production was realized on 3.9 million areas in the world in 2017 and the average yield was 18.98 tons / hectare. Turkey's average yield was 37.98 tons / hectare and exceeded the world average yield. (TEPGE, 2020) Unlike other agricultural products, the rate of productivity is high in oranges. The support model implemented in Turkey in orange cultivation should be provided to other areas. In other words, it is necessary to determine the marginal limits of the supports that encourage productivity in production, otherwise we can see some field products where production is abandoned (Kilic, Boz \& Eryilmaz, 2020).

Table 3

Tea export prices by country (2019)

\begin{tabular}{lc}
\hline Countries & USD Dollar /ton \\
\hline France & 17.065 \\
Germany & 9.241 \\
England & 8.277 \\
Netherlands & 5.014 \\
Turkey & 3.650 \\
\hline
\end{tabular}

Source: FAO

Finally, the table 3 showing the export prices of tea by country is given. This table reveals the importance of branding and sales marketing practices in terms of agricultural products and economy. The high production costs of Turkish tea cannot compete sufficiently in the foreign market with the low costs of other producer and exporting countries (Seyis et al., 2018). Turkey, tea made intensive use of fertilizers in the land and harm the environment, but especially the lack of control lowers the productivity of the land. In addition, it has a disadvantage due to the aging of the tea gardens, due to the fact that new tea gardens are not created.

For the other hand, it is known that a significant human resource in developing countries is idle and a great majority of them create a potential burden on the agricultural economy. Considering the outcome of this situation, it is acceptable to have an economic recession (WB, 2020). Because while it is expected that the skilled and non-specialized population of the labor 
force will contribute to the agricultural economy with a great effort, the situation that is considered as a problem brings to mind the question of whether this workforce exists and cannot be used properly, or whether the agricultural economy produced by the workforce falls short of creating added value (Miller, 2020).

Within the framework of the information stated so far, in recent years, the total agricultural production and agricultural sector employment rates and the changes in agricultural growth have made it necessary to conduct a study on determining the factors that can affect economic growth (Seyis et al., 2018). In addition, the fact that such an up-to-date study conducted specifically for European countries is almost non-existent reveals the importance of this research.

Figure 1: Agriculture, value added (\% of GDP) (Worldbank data)

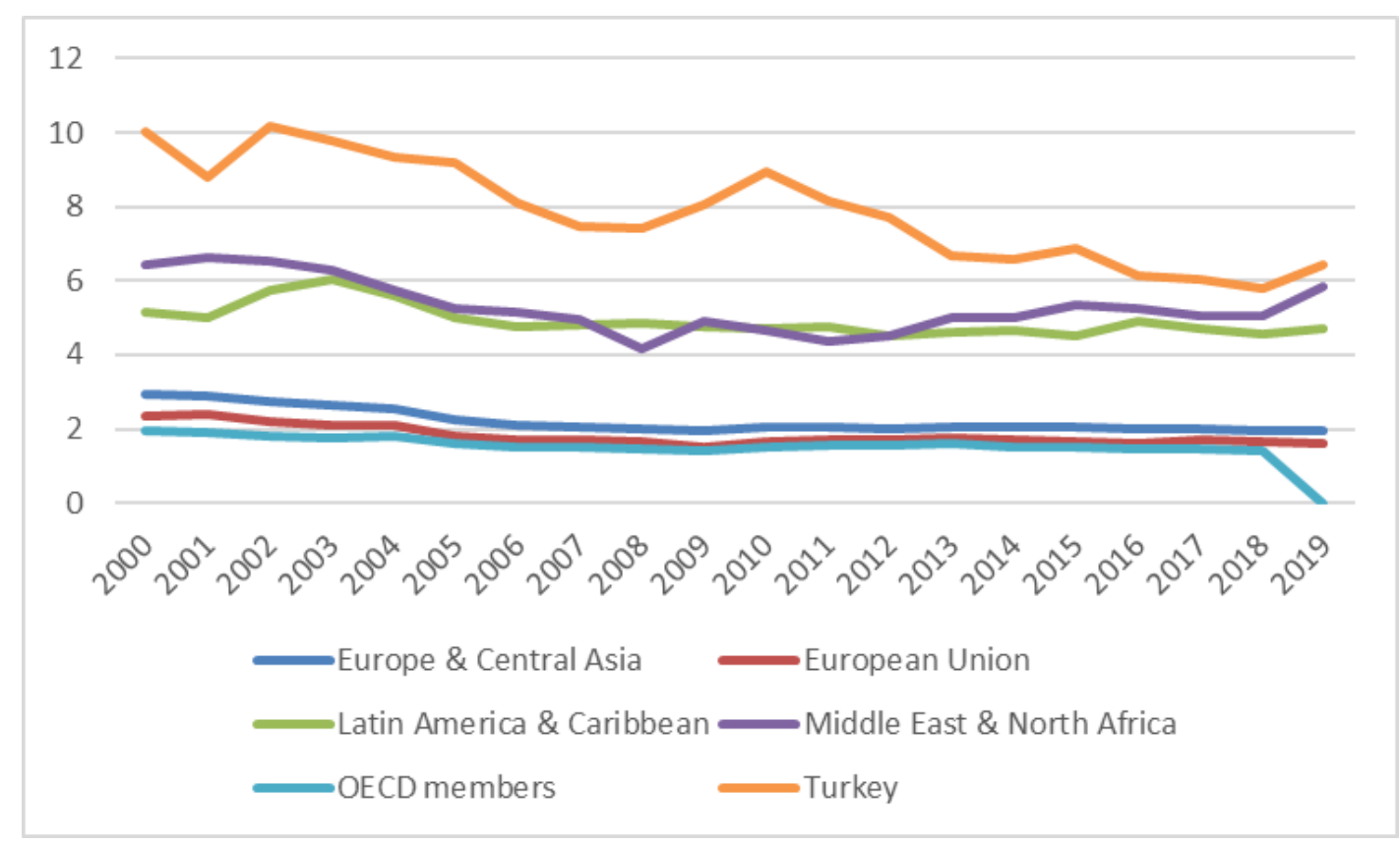

The figure 1 shows the percentage of agricultural value in the GDP of some country groups. Agricultural added value in Latin America, Middle East, North Africa and Turkey are significant level. However, this value has been decreasingly growing in the last 20 years.

In this case, Sandalc1lar (2012) made a causality analysis of the relationship between total exports, agricultural exports, non-agricultural exports and economic growth. The contribution of agricultural exports to the validity of the export-led growth hypothesis could 
not be estimated. This situation showed that the main determinant of growth in total exports is non-agricultural exports. Terin et al. (2013) tried to determine the economic factors affecting agricultural growth. It can see that the value created by the agricultural economy positively contributes to the economic growth of countries and the development of a sustainable agricultural sector will be very important, so that it will meet the needs of the industrial sector and contribute to economic prosperity in the long term, which will have a multiplier effect on economic growth and development, according to Rakhmetullina et al. (2017).

The increase in agricultural production and the increase in the per capita income of the rural population, along with industrialization and urbanization, lead to an increase in the demand for industrial production. Increased agricultural production and productivity are seen to contribute to the country's overall economic growth, it would be reasonable and fitting to put greater emphasis on agriculture (Pingali, 2007). Agricultural growth and economic development: a view through the globalization lens. It should not be forgotten that strategies such as neglecting agriculture, not being developed despite the lack of industrialization rent, or excessive focus on industrialization can delay economic growth both in the short and long term.

Will agriculture make a difference? Do countries' GDP sizes and increasing global interconnectedness see the agricultural sector inevitable? Are countries really successful or are they doing the agricultural transformation out of necessity, or haven't they done so yet? So how should the transformation be? These questions will be answered first with empirical analysis and then dealt with conclusively in the remainder of the article.

\section{Methodology}

In this part of the study, the definition of the data used in the study, cross-section dependency tests, stability tests of variables, cointegration tests, long and short-term analysis with panel ARDL will be evaluated together with all empirical results. Panel Autoregressive Distributed Lag (ARDL) is the inclusion of the lagged values of dependent and independent variables in the regression model applied to time series. The reason why Panel ARDL is preferred as an empirical method is that the effects of the variables in the study on national income can be determined and detailed results can be determined with the comparative analysis of the countries in the study. In addition, with the ARDL application, it is aimed to 
determine the short- and long-term relationships between national income and these variables. In other words, the significance of the considered panel's temporal dimension suggests, in our opinion, the probability of a long-run relationship between the variables and the resulting causal linkages. We used an autoregressive distributed lag (ARDL) model, also known as the bound testing cointegration technique, which was first proposed by Pesaran et al. (2001).

In this study, the variables of national income, total agricultural production and agricultural sector employment rate were obtained from World Bank open data sources. Econometric analysis was performed using EViews with annual data covering the period 2000 and 2019. The table 4 below explains the dependent and independent variables to be used in this study, and the sources and descriptive statistics of the data are specified. Logarithmic transformation has been applied to all series.

Table 4

Descriptive statistics

\begin{tabular}{llllllcc}
\hline Variable & & Mean & Std. Dev. Min & Max & Observations \\
\hline lgdp & overall & 27.9902 & 0.721113 & 26.03031 & 29.00822 & $\mathrm{~N}=$ & 100 \\
& between & & 0.729578 & 27.11426 & 28.77495 & $\mathrm{n}=$ & 5 \\
& Within & & 0.299792 & 26.90625 & 28.46384 & $\mathrm{~T}=$ & 20 \\
lagri & overall & 24.1186 & 0.495159 & 22.98216 & 24.96704 & $\mathrm{~N}=$ & 100 \\
& between & & 0.495498 & 23.31966 & 24.55872 & $\mathrm{n}=$ & 5 \\
& Within & & 0.216294 & 23.15841 & 24.52691 & $\mathrm{~T}=$ & 20 \\
empagr & overall & 7.43579 & 9.366643 & 1.21 & 39.317 & $\mathrm{~N}=$ & 100 \\
& between & & 9.956471 & 1.8526 & 25.1894 & $\mathrm{n}=$ & 5 \\
& Within & 2.761863 & 0.622389 & 21.56339 & $\mathrm{~T}=$ & 20 \\
\hline
\end{tabular}

\section{Results}

Model GDP was created as follows by accepting that it is a function of AGRI and EMPAGR.

$$
G D P_{i t}=f\left(A G R I_{i t}, E M P A G R_{i t}\right)
$$

Here:

$G D P_{i t}=$ national income of country $\mathrm{i}$ in period $\mathrm{t}, A G R I_{i t}=$ agricultural income of country $\mathrm{i}$ in period t, EMPAGR $R_{i t}=$ share of agricultural workers in total employment for country $\mathrm{i}$ in period $\mathrm{t}, \dot{\mathrm{I}}=1,2,3,4,5$ (number of countries), $\mathrm{t}=1,2,3 \ldots \ldots, 20$ (time dimension) is referred. 
When conducting econometric analysis, one of the most important issues to be considered in order to reach the correct result is that the series are stationary. The time series is stationary if the mean and variance of the time series are constant over time and the covariance between the two periods is not dependent on the time of the observed variables but on the distance between the two periods. If the series is not stationary, it cannot maintain its average in the long term and the variance value goes away as the time approaches infinity. Autocorrelation values move away from zero as the number of lags increases, R2 values are high and t statistics values are significant. Thus, the model estimates obtained in the long term cannot give accurate results and a spurious regression model emerges.

In the study, it was first examined whether there is a cross-sectional dependency between variables. The existence of cross-section dependence also requires the application of tests that take into account the cross-section dependency in selecting the methods to be used in the following stages. If there is no cross-sectional dependency, first-generation unit root tests, otherwise, second-generation unit root tests, which also take into account cross-sectional dependence, should be used.

\section{Cross section dependency test}

Generally, error terms between units in panel data models are assumed to be uncorrelated. This is especially true for panels with large cross-sectional dimensions. Since the study covers several units and a relatively long period, cross-sectional dependency should be examined. The accuracy of later unit root tests depends on the results obtained here. Although various tests are available, the Breusch-Pagan (1980) LM test has been deemed appropriate because it has few section units but has a relatively long duration. Table 5, It shows the correlation matrix between equations and performs a Breusch-Pagan test for these equations.

Table 5

Correlation matrix

\begin{tabular}{llllll}
\hline \multicolumn{6}{c}{ Correlation matrix of residuals } \\
\hline & e1 & e2 & e3 & e4 & e5 \\
e1 & 1.0000 & & & & \\
e2 & -0.4088 & 1.0000 & & & \\
e3 & -0.5806 & 0.2746 & 1.0000 & & \\
e4 & -0.3022 & 0.3296 & 0.5811 & 1.000 & \\
e5 & -0.4201 & 0.4960 & 0.7592 & 0.6658 & 1.0000 \\
\hline
\end{tabular}


Breusch-Pagan LM test of indepence $:$ chi2 $(10)=51.190, \mathrm{pr}=0.0000$

Based on 20 complete observations over panel units (Eviews are results)

Since the null hypothesis expressing cross section independence is rejected, second generation unit root tests should be used. According to the unit root test results, it is concluded that the series have a unit root when they are in a level. However, when the first differences are taken, it is stationary according to the $5 \%$ significance level.

\section{Cointegration process}

After testing whether the series contain unit root or not, it was seen that the series were stationary at I (1) level and whether there was a long-term mutual relationship was investigated by Pedroni (1999) and Kao (1999) panel cointegration tests. The appropriate lag lengths that overcome the autocorrelation problem were determined with the Schwarz information criterion.

Of the seven test statistics calculated for the Pedroni test, four reject the null hypothesis. However, since the Kao test statistics also rejected the null hypothesis, we conclude that the series are co-integrated.

\section{Table 6}

Pedroni residual cointegration test

\begin{tabular}{lclll}
\hline \multicolumn{2}{l}{ Series: LGDP LEMPAGR LAGRI } & & \\
& & & Weighted & \\
& $\underline{\text { Statistic }}$ & $\underline{\text { Prob. }}$ & $\underline{\text { Statistic }}$ & $\underline{\text { Prob. }}$ \\
Panel v-Statistic & 0.780475 & 0.2176 & 0.801036 & 0.2116 \\
Panel rho-Statistic & -0.329598 & 0.3709 & -0.319932 & 0.3745 \\
Panel PP-Statistic & -1.797497 & 0.0361 & -1.691333 & 0.0454 \\
Panel ADF-Statistic & -1.769045 & 0.0384 & -1.656095 & 0.0489
\end{tabular}

Alternative hypothesis: individual AR coefs. (between-dimension)

\begin{tabular}{lcl} 
Group rho-Statistic & $\underline{\text { Statistic }}$ & $\underline{\text { Prob. }}$ \\
Group PP-Statistic & -1.747572 & 0.7148 \\
Group ADF-Statistic & -1.471593 & 0.0406 \\
\hline
\end{tabular}

After the unit root test results, we can see that there is cointegration between variables and the result of this cointegration is supported in Tables 6 and 7. 
Table 7

Kao residual cointegration test

\begin{tabular}{|c|c|c|}
\hline Series: LGDP LEMPAGR LAGRI & & \\
\hline $\mathrm{ADF}$ & $\begin{array}{l}\text { t-Statistic } \\
-5.043846\end{array}$ & $\begin{array}{l}\text { Prob. } \\
0.0000\end{array}$ \\
\hline Residual variance & 0.004812 & \\
\hline HAC variance & 0.003910 & \\
\hline
\end{tabular}

After the unit root test results, we can see that there is cointegration between variables and the result of this cointegration is supported in Tables 6 and 7.

\section{Model estimation}

Panel ARDL (p, q, q..., q) model, can be shown as follows.

$$
\Delta Y_{i t}=\theta_{i}\left[Y_{i, t-1}-\lambda^{\prime}{ }_{i} X_{i, t}\right]+\sum_{j=1}^{p-1} \xi_{i j} \Delta Y_{i, t-j}+\sum_{j=0}^{q-1} \beta^{\prime}{ }_{i j} \Delta X_{i, t-j}+\varphi_{i}+e_{i t}
$$

Here:

$\theta_{i}$ : Adjustment coefficient, $\lambda^{\prime}{ }_{i}$ : Long term relation vector, $\left[Y_{i, t-1}-\lambda^{\prime}{ }_{i} X_{i, t}\right]$ : Error correction term

$\xi_{i, j}, \beta^{\prime}{ }_{i j}:$ short-term relation coefficient are referred.

After determining the optimal lag length according to AIC criteria in Eviews, the ARDL $(2,2,2)$ model was estimated with PMG and MG estimators and the results are given in the table.

Table 8

Estimation results

\begin{tabular}{|c|c|c|c|c|c|c|c|c|}
\hline \multirow{2}{*}{$\begin{array}{l}\mathrm{N}=5 \\
\mathrm{~T}=20 \\
\quad \text { Long } \text { term }\end{array}$} & \multirow{2}{*}{$\begin{array}{l}\text { ARDL }(2,2,2) \\
\text { Coeff. }\end{array}$} & \multicolumn{3}{|c|}{ PMG results } & \multicolumn{4}{|c|}{ MG results } \\
\hline & & Std Err & $\begin{array}{l}\mathrm{t}- \\
\text { statistic }\end{array}$ & Prob. & Coeff. & Std Err & $\begin{array}{l}\text { t- } \\
\text { statistic }\end{array}$ & Prob. \\
\hline LAGRI & 0.8410522 & 0.107753 & 7.81 & 0 & 0.902605 & 0.3388781 & 2.66 & 0.008 \\
\hline LEMPAGR & -0.0289062 & 0.007999 & -3.61 & 0 & -0.00772 & 0.0363011 & -0.21 & 0.832 \\
\hline \multicolumn{9}{|l|}{ Short term } \\
\hline ECT & -0.3968832 & 0.082342 & -4.82 & 0 & -0.54844 & 0.1490967 & -3.68 & 0 \\
\hline$\Delta \operatorname{LGDP}(-1)$ & 0.0721239 & 0.025711 & 2.81 & 0.005 & 0.015311 & 0.0457212 & 0.33 & 0.738 \\
\hline$\Delta$ LAGRI & 0.5614012 & 0.054925 & 10.22 & 0 & 0.680982 & 0.1422064 & 4.79 & 0 \\
\hline$\Delta$ LAGRI(-1) & -0.0225197 & 0.101308 & -0.22 & 0.824 & -0.14985 & 0.1457207 & -1.03 & 0.304 \\
\hline$\triangle$ LEMPAGR & -0.1994049 & 0.127769 & -1.56 & 0.119 & -0.23006 & 0.1383491 & -1.66 & 0.096 \\
\hline$\Delta$ LEMPAGR(-1) & -0.1041721 & 0.143182 & -0.73 & 0.467 & -0.22171 & 0.1936482 & -1.14 & 0.252 \\
\hline $\mathrm{C}$ & 3.108 .832 & 0.55075 & 23498 & 0 & -0.16938 & 3248138 & -0.05 & 0.958 \\
\hline
\end{tabular}


According to Table 8, long-term parameters are found to be significant, and a $1 \%$ increase in long-term LAGRI increases GDP 'by 0.84 percent. The test results in tables 9 support these significant findings and show that the error correction term works at a significant level between -1 and 0 . The short-term parameters of the LAGRI variable are significant and we see that in the current period, the GDP reacts to the short-term change in LAGRI in the same period.

Before interpreting the results, it was concluded that the PMG estimator is effective and consistent, since the Chi square tail probability is greater than 0.05 in the Hausman test, which was conducted to decide which is the effective and consistent estimator.

Table 9

PMG estimates table

\begin{tabular}{lrrrc}
\hline Long term & Coefficiency & Std Err & t-statistic & Probability \\
\hline LAGRI & 0.8410522 & 0.107753 & 8.4 & 0 \\
LEMPAGR & -0.0289062 & 0.007999 & -3.61 & 0 \\
Short term & & & & \\
ECT & -0.3968832 & 0.082342 & -4.82 & 0 \\
$\Delta$ LGDP(-1) & 0.0721239 & 0.025711 & 2.88 & 0.005 \\
$\Delta$ LAGRI & 0.5614012 & 0.054925 & 10.38 & 0 \\
$\Delta$ LAGRI(-1) & -0.0225197 & 0.101308 & -0.22 & 0.824 \\
$\Delta$ LEMPAGR & -0.1994049 & 0.127769 & -1.56 & 0.119 \\
$\Delta$ LEMPAGR(-1) & -0.1041721 & 0.143182 & -0.73 & 0.467 \\
C & 3.108 .832 & 0.55075 & 5.65 & 0 \\
\hline
\end{tabular}

When the short-term parameters were analyzed according to the panel ARDL test results for Turkey, Netherlands, Germany, France and Italy, the error correction term was found to be statistically significant and negative. In other words, when our variables with a long-term balance relationship deviate from balance with a shock, they correct this deviation by $40 \%$ in a period. In the short term, the agricultural employment rate was found to be insignificant. In the current period, $1 \%$ increase in agriculture income increases national income by $0.56 \%$, and this does not affect national income for the next period. Long-term parameters are found to be significant, and a $1 \%$ increase in agricultural income increases national income by $0.84 \%$. The $1 \%$ increase in the agricultural workforce decreases the national income by $2.8 \%$; in other words, the agricultural sector continues to be the main element of the world economy for many years.

At the same time, this importance will continue as it is an area where the basic needs of humanity are met. For this reason, in this article, where the national income, total agricultural 
production and agricultural sector employment rate data of some important agricultural countries are evaluated empirically; 2000 and Turkey in 2019, the Netherlands, Germany, France and Italy as a factor of ensuring the increase in agricultural income, the manufacturer support is inevitable, of qualified human resources in addition it has revealed that it is important to increase agriculture's favor. Otherwise, it is not sustainable to keep qualified human resources only in city centers or factories in the world economy, where unemployment has grown like an avalanche in recent years. Therefore, since raising qualified human resources in the agricultural sector may indirectly cause an increase in agricultural incomes, the stable growth and even development of countries will only be possible with such a transformation.

\section{Discussion}

Contribution of agricultural economic values to economic growth; Population and workforce, Obtaining foreign currency income by exporting agricultural products, Industry sector and National income, etc. it is discussed from time to time in many areas. Praburaj et al.,2018; Suryahadi et al.,2012; Norton et al.,2014). Reports on a local and international basis provide a broad view on the production and productivity of agricultural products. The results of the table 8 and table 9 empirical study also support this. Short-term agricultural employment data were found to be insignificant, and it is considered that this will be related to the flexibility of employment in agriculture. On the other hand, agricultural national income increased, but the share of agricultural national income in GDP decreased.

While total agricultural production, agriculture sector employment rate, total fixed capital investments in agriculture, agricultural supports and the share of agriculture in GDP affect agricultural growth positively, it has been determined that the number of populations employed in agriculture adversely affects agricultural growth and is consistent with the results of the analysis we have obtained (Terin et al., 2013; Armas et al., 2012; Lopez \& Galinao, 2007; Fan et al., 2008; Alcott et al., 2006) In addition, it is similar to other studies in the literature that the increase in the number of people employed in agriculture will affect the economic growth negatively (Haggblade, 2010; Reardon et al., 2001; Ansari \& Khan, 2018).

COVID-19 is projected to have a far higher total economic impact than previous global economic crises, such as the global economic crisis of 2007-2008 (UNDP, 2021). The World Bank estimates that the economic effects will force around 100 million people into extreme poverty (WB, 2020). According to the International Food Policy Research Institute (IFPRI), 
the economic downturn in 2020 might raise the number of people living in extreme poverty by $20 \%$, or 140 million people, resulting in increased food insecurity in many nations (IFPRI, 2020). Soaring unemployment rates, income losses, and growing food costs, according to the FAO, are jeopardizing food access in both industrialized and developing countries. Each percentage point decrease in global GDP is anticipated to result in 700,000 more stunted children. Small-scale farmers and their families, food workers in all sectors, and people who live in commodities and tourism-based economies are all particularly vulnerable (FAO, 2020 a). The FAO issued proposals for policy actions that governments may implement right from the start of the crisis, arguing that the global recession might leave tens of millions of people hungry, especially in impoverished countries that rely on food imports (FAO, $2020 \mathrm{~b}$; IFPRI, 2020; Elleby, 2020; UNDP, 2021).

Agriculture in the world is going in a new direction and a production based on technology is taking place (Singh et al., 2020). Turkey's traditional agricultural events which continue to lag behind other countries in this way; is the fact that modern agriculture understanding has not been adopted. Turkish farmers should be trained properly, the suitability of the soil and climate to the crop should be checked and the right crop should be planted in the right area. For example, as a result of researches suitable for the region where wheat is low, one, two or more alternative products should be planted instead of wheat.

Agriculture modernization is a vital issue come to forefront frequently in recent years in Turkey (Uyan, 2017). Thanks to early warning systems, it is aimed to save the farmer from agricultural damage and pests and to use the correct fertilizer and water. In order for the project, which has not yet become widespread, to be implemented in accordance with the realities of the country, the awareness of the farmers should be increased, and the necessary and sufficient training should be provided in the beginning process. Thus, sustainability will be achieved in this area as well. In addition to this, in order to increase the productivity in agricultural products, it is necessary to diversify the production in order for farmers to be less affected by price fluctuations.

For example, if a wheat and barley producer produce beer with a part of this production and sells it in domestic and / or foreign markets, it will protect the producer from price fluctuations and at the same time increase the export volume of the country (De Roest, Ferrari $\&$ Knickel, 2018). These product diversification practices, which appear to be very profitable theoretically, are almost impossible without subsidies, training and other government support. 
An agricultural producer, family or small business owner, on the other hand, will not be able to carry out activities such as producing in the field, creating a new product with some of this production, finding new markets for this product.

For the other hand, Turkey reached the highest figure in imports due to the wrong policies in agriculture. Once a self-sufficient country, it has become foreign dependent. Nowadays, like the whole world, it is faced with the imminent global food and water crisis. However, with the right practices, both the agricultural reform should be implemented, and the economic and socioeconomic rise of the country will be realized with this reform. Turkey does not have the players for the role of government alone will make these reforms in the private sector is of vital importance, as can be seen in the study of Tansel (2019). In order for this change to happen, education, engineering and many branches of science are also needed besides agriculture. This assessment is supported by other studies (Aydogan \& Vardar, 2020; Khan et al., 2020). At the same time, this change will enable agriculture to play an important role in exports, as in another study with similar findings (Hwa, 1988; Dawson, 2005; Michler, 2020)

The limitations of this study measure the discussion about the role of agriculture in promoting economic growth in selected countries with the variables used in the model. Of course, significant more different variables can alter the interpretation of the results. However, we see that the reliability of the study model is at a high level in terms of getting rational results in the literature and in practice.

\section{Conclusion}

In this study, the variables of national income, total agricultural production and agricultural sector employment rate are obtained from World Bank resources and econometric analysis is carried out with annual data covering the period between 2000 and 2019. According to the findings of the study; In the current period, $1 \%$ increase in agriculture income increases national income by $0.56 \%$, and this does not affect national income for the next period. Longterm parameters are found to be significant, and a $1 \%$ increase in agricultural income increases national income by $0.84 \%$. The $1 \%$ increase in the agricultural workforce decreases the national income by $2.8 \%$.

The share of agriculture in GDP and employment are declining. All factors considered show that there is an increase in labor force in non-agricultural sectors due to the decrease in agricultural productivity. The relatively low value of agricultural production results in 
products containing less agricultural products, as well as high costs and unemployment. We can see the ongoing decline in agricultural production by transferring it to unskilled labor in non-agricultural sectors. For this reason, ensuring adequate production, keeping imports at a low level, directing human resources to qualified areas, regardless of whether agriculture is the primary sector or not, will positively affect economic growth. Because agricultural countries need time and energy by exporting their agricultural surpluses, and we think that if they move away from the marginal benefit and cost line, then the agricultural added value will decrease on economic growth. Eventually, the share of agricultural trade in GDP will decrease. For this reason, keeping the agricultural sector employment rate and agricultural production marginally at productivity levels is necessary for the sustainability of economic growth.

\section{References}

Allcott, H., Lederman, D., \& López, R. (2006). Political institutions, inequality, and agricultural growth: The public expenditure connection. Washington, DC., USA: The World Bank. https://elibrary.worldbank.org/doi/abs/10.1596/1813-9450-3902)

Andrés-Domingo, J. A., \& Hernando-Castellet, I. (1997). Does inflation harm economic growth?: evidence for the OECD. Documentos de trabajo/Banco de España, 9706. https://dialnet.unirioja.es/servlet/articulo?codigo $=896636$

Ansari, S. A., \& Khan, W. (2018). Relevance of declining agriculture in economic development of South Asian countries: An empirical analysis. AGRIS on-line Papers in Economics and Informatics, 10, 3-14. https://ageconsearch.umn.edu/record/276108/.doi: 10.22004/ag.econ.276108

Armas, E. B., Gómez-Osorio, C., \& Moreno-Dodson, B. (2012). Agriculture public spending and growth: The example of Indonesia. World Bank Policy Research Working Papers. Washington, D. C.: World Bank.

Arnold, T., Blokland, K., Engel, A., Ifejika Speranza, C., Losch, B., Michel, B., ... \& Zvarimwa, M. (2019). An Africa-Europe agenda for rural transformation. doi: 10.7892/boris. 130615

Aydoğan, B., \& Vardar, G. (2020). Evaluating the role of renewable energy, economic growth and agriculture on $\mathrm{CO} 2$ emission in $\mathrm{E} 7$ countries. International Journal of Sustainable Energy, 39 (4), 335-348. https://doi.org/10.1080/14786451.2019.1686380

Barro, R. J. (1995). Inflation and economic growth. Bank of England Quarterly Bulletin, 35 (2): 407-443. https://www.bankofengland.co.uk/quarterly-bulletin/1995/q2/inflationand-economic-growth 
Black, D. C., Dowd, M. R. \& Keith, K. (2001). The inflation/growth relationship: evidence from state panel data. Applied Economics Letters, 8 (2): 771-774. https://doi.org/10.1080/13504850110044202

Burdekin, R. C., Goodwin, T., Salamun, S., \& Willett, T. D. (1994). The effects of inflation on economic growth in industrial and developing countries: is there a difference? Applied Economics Letters, 1 (10), 175-177. https://doi.org/10.1080/135048594357952

Castaneda, R., Doan, D., Newhouse, D. L., Nguyen, M., Uematsu, H., \& Azevedo, J. P. (2016). Who are the poor in the developing world? World Bank Policy Research Working Paper, 7844. https://papers.ssrn.com/sol3/papers.cfm?abstract_id=2848472

Çelik, D. (2020). Inflation across income groups: the case of Turkey [Master's thesis, Middle East Technical University].

Chowdhury, A. (2002). Does inflation affect economic growth? The relevance of the debate for Indonesia. Journal of the Asia Pacific Economy, 7 (1), 20-34. https://doi.org/10.1080/13547860120110452

Cobre, A. F., Surek, M., Vilhena, R. O., Böger, B., Fachi, M. M., Momade, D. R., ... \& Pontarolo, R. (2021). Influence of foods and nutrients on COVID-19 recovery: A multivariate analysis of data from 170 countries using a generalized linear model. Clinical Nutrition. https://doi.org/10.1016/j.clnu.2021.03.018

COMCEC (2018). Improving Agricultural Market Performance: Developing Agricultural Market Information Systems. The Standing Committee for Economic and Commercial Cooperation of the Organization of the Islamic Cooperation. Comcec Coordination Office. February, 2018.

Dawson, P. J. (2005). Agricultural exports and economic growth in less developed countries. Agricultural economics, 33 (2), 145-152. https://doi.org/10.1111/j.15740862.2005.00358.x

De Roest, K., Ferrari, P., \& Knickel, K. (2018). Specialization and economies of scale or diversification and economies of scope? Assessing different agricultural development pathways. Journal of Rural Studies, 59, 222-231. https://doi.org/10.1016/j.jrurstud.2017.04.013

Dhahri, S., \& Omri, A. (2020). Foreign capital towards SDGs 1 \& 2-Ending Poverty and hunger: The role of agricultural production. Structural Change and Economic Dynamics, 53, 208-221. https://doi.org/10.1016/j.strueco.2020.02.004

Elleby, C., Domínguez, I. P., Adenauer, M., \& Genovese, G. (2020). Impacts of the COVID19 pandemic on the global agricultural markets. Environmental and Resource Economics, 76(4), 1067-1079. https://doi.org/10.1007/s10640-020-00473-6

Fan, S., Gulati, A., \& Thorat, S. (2008). Investment, subsidies, and pro-poor growth in rural $\begin{array}{lllll}\text { India. } & \text { Agricultural } & \text { Economics, } & 39 & \text { (2), }\end{array}$ https://onlinelibrary.wiley.com/doi/abs/10.1111/j.1574-0862.2008.00328.x 
FAO 1. http://www.fao.org/faostat/en/\#data/QC/visualize. Accessed 26.01.2020

FAO. (2020, a). Food Outlook - Biannual Report on Global Food Markets: June 2020. Food Outlook, 1. Rome. Retrieved from https://doi.org/10.4060/ca9509en

FAO. (2020, b). Policy tools and publications to assist countries to respond to the novel coronavirus (COVID-19) crisis. Retrieved from http://www.fao.org/policysupport/coronavirus-pandemic/en/

Gillman, M., Harris, M., \& Mátyás, L. (2009). Inflation Theory in Economics: Welfare, Velocity, Growth and Business Cycles. London: Routledge. https://doi.org/10.4324/9780203880180

Gillman, M., \& Kejak, M. (2005). Contrasting models of the effect of inflation on growth. Journal of Economic Surveys, 19 (1), 113-136. https://doi.org/10.1111/j.09500804.2005.00241.x

Gollin, D. (2010). Agricultural productivity and economic growth. Handbook of agricultural economics, 4, 3825-3866. https://doi.org/10.1016/S1574-0072(09)04073-0.

Haggblade, S., Hazell, P., \& Reardon, T. (2010). The rural non-farm economy: Prospects for growth and poverty reduction. World development, 38 (10), 1429-1441. https://doi.org/10.1016/j.worlddev.2009.06.008

Hanjra, M. A., \& Qureshi, M. E. (2010). Global water crisis and future food security in an era $\begin{array}{lllll}\text { of climate change. Food policy, } 35 & \text { (5), 365-377. }\end{array}$ https://doi.org/10.1016/j.foodpol.2010.05.006

Havemann, T., Negra, C., \& Werneck, F. (2020). Blended finance for agriculture: exploring the constraints and possibilities of combining financial instruments for sustainable transitions. Agriculture and Human Values, 37 (4), 1281-1292.

Hodge, D. (2006). Inflation and growth in South Africa. Cambridge Journal of Economics, 30 (2), 163-180. https://doi.org/10.1093/cje/bei051

Hwa, E. C. (1988). The contribution of agriculture to economic growth: some empirical evidence. World development, 16 (11), 1329-1339. https://doi.org/10.1016/0305750X(88)90208-2

IFPRI. (2020). Poverty and food insecurity could grow dramatically as COVID-19 spreads. (D. Laborde Debucquet, W. Martin, \& R. Vos, Editors) Retrieved from https://doi.org/10.2499/p15738coll2.133762_02

Jatuporn, C., Chien, L. H., Sukprasert, P., \& Thaipakdee, S. (2011). Does a long-run relationship exist between agriculture and economic growth in Thailand. International Journal of Economics and Finance, 3 (3), 227-233. https://pdfs.semanticscholar.org/97e0/eefcf939aba65921385cacbc15df040d0b68.pdf) 
Khan, W., Jamshed, M., \& Fatima, S. (2020). Contribution of agriculture in economic growth: A case study of West Bengal (India). Journal of Public Affairs, 20 (2), e2031. https://doi.org/10.1002/pa.2031

Kılıç, O., Boz, İ., \& Eryılmaz, G. A. (2020). Comparison of conventional and good agricultural practices farms: A socio-economic and technical perspective. Journal of Cleaner Production, 258. https://doi.org/10.1016/j.jclepro.2020.120666

Kim, S., \& Willett, T. D. (2000). Is the negative correlation between inflation and growth real? An analysis of the effects of the oil supply shocks. Applied Economics Letters, 7 (3), 141-147. https://doi.org/10.1080/135048500351681

Lains, P., \& Pinilla, V. (Eds.). (2008). Agriculture and economic development in Europe since 1870. London: Routledge Taylor and Francis Group.

Liu, Z., He, C., Zhou, Y., \& Wu, J. (2014). How much of the world's land has been urbanized, really? A hierarchical framework for avoiding confusion. Landscape Ecology, 29 (5), 763-771. https://doi.org/10.1007/s10980-014-0034-y

López, R., \& Galinato, G. I. (2007). Should governments stop subsidies to private goods? Evidence from rural Latin America. Journal of Public Economics, 91 (5-6), 1071-1094. https://doi.org/10.1016/j.jpubeco.2006.10.004

Matsuyama, K. (1992). Agricultural productivity, comparative advantage, and economic growth. Journal of economic theory, 58 (2), 317-334. https://doi.org/10.1016/00220531(92)90057-O

Meijerink, G., \& Roza, P. (2007). The role of agriculture in development. Markets, Chains and Sustainable Development Strategy and Policy Paper, 5. http://www.boci.wur.nl/UK/Publications/

Menker, S. (2017). A global food crisis may be less than a decade away. TED Global 2017. https://www.ted.com/talks/sara_menker_a_global_food_crisis_may_be_less_than_a_d ecade_away

Michler, J. D. (2020). Agriculture in the process of development: A micro-perspective. World Development, 129, 104-118. doi: 10.1016/j.worlddev.2020.104888

Miller, M. M. (2020). Economic Development at the Community Level: Creating Local Wealth and Resilience in Developing Countries. London: Routledge.

Motley, B. (1998). Growth and inflation: a cross-country study. Federal Reserve Bank of San Francisco Economic Review, 1, 15-28. http://www.frbsf.org/econrsrch/econrev/981/15-28.pdf

Nie, W., Li, T., \& Zhu, L. (2020). Market demand and government regulation for quality grading system of agricultural products in China. Journal of Retailing and Consumer Services, 56, 102-134. https://doi.org/10.1016/j.jretconser.2020.102134 
Norton, G. W., Alwang, J., \& Masters, W. A. (2014). Economics of agricultural development: World food systems and resource use. London: Routledge.

Omorogiuwa, O., Zivkovic, J., \& Ademoh, F. (2014). The role of agriculture in the economic development of Nigeria. European Scientific Journal, 10 (4). https://doi.org/10.1177/2158244019899045

Pelek, D. (2019). Syrian refugees as seasonal migrant workers: Re-construction of unequal power relations in Turkish agriculture. Journal of Refugee Studies, 32 (4), 605-629. https://doi.org/10.1093/jrs/fey050

Pesaran, M. H., Shin, Y., \& Smith, R. J. (2001). Bounds testing approaches to the analysis of level relationships. Journal of applied econometrics, 16 (3), 289-326. https://doi.org/10.1002/jae.616

Pingali, P. (2007). Agricultural growth and economic development: a view through the globalization lens. Agricultural Economics, 37, 1-12. https://doi.org/10.1111/j.15740862.2007.00231.x

Praburaj, L., Design, F., \& Nadu, T. (2018). Role of agriculture in the economic development of a country. Shanlax International Journal of Commerce, 6 (3), 1-5. https://doi.org/10.5281/zenodo.1323056

Pulighe, G., \& Lupia, F. (2020). Food first: COVID-19 outbreak and cities lockdown a booster for a wider vision on urban agriculture. Sustainability, 12(12), 5012. https://doi.org/10.3390/su12125012

Rakhmetullina, S., Isiksal, A. Z., \& Chimezi, J. O. (2017). Economic Growth, Agriculture and Industrialization in Nigeria: an ARDL Bound Testing Approach. International Journal of Economic Perspectives, 11 (2).

Raza, S. A., Ali, Y., \& Mehboob, F. (2012). Role of agriculture in economic growth of Pakistan. International Research Journal of Finance and Economics, 83, 180-186. https://mpra.ub.uni-muenchen.de/32273/

Reardon, T., Berdegué, J., \& Escobar, G. (2001). Rural nonfarm employment and incomes in Latin America: overview and policy implications. World development, 29 (3), 395409. https://doi.org/10.1016/S0305-750X(00)00112-1

Sandalcilar, A. R. (2012). Türkiye'de tarımsal ihracat, tarım dışı ihracat ve ekonomik büyüme arasındaki ilişkinin nedensellik analizi. Finans Politik ve Ekonomik Yorumlar Dergisi, 49 (5), 65-76. https://dergipark.org.tr/tr/pub/fpeyd/issue/48064/607741

Seyis, F., Yurteri, E., Ozcan, A., \& Savsatl1, Y. (2018). Organic tea production and tea breeding in Turkey: challenges and possibilities. Ekin Journal of Crop Breeding and Genetics, 4 (1), 60-69. https://dergipark.org.tr/en/download/article-file/445475

Singh, M., Kumar, P., Kumar, V., Solanki, I. S., Mcdonald, A. J., Kumar, A., \& Malik, R. K. (2020). Intercomparison of Crop Establishment Methods for İmproving Yield and 
Profitability in The Rice-Wheat System of Eastern India. Field Crops Research, 250, 107-116. https://doi.org/10.1016/j.fcr.2020.107776

Subaşı, O.S., \& Ören, M.N., (2013). Türkiye'de tarımsal Ar-Ge harcamaları ve tarımsal büyüme ilişkileri. Akdeniz Üniversitesi Ziraat Fakültesi Dergisi, 26 (2), 99-104. https://dergipark.org.tr/en/pub/akdenizfderg/issue/1563/19375

Suryahadi, A., Hadiwidjaja, G., \& Sumarto, S. (2012). Economic growth and poverty reduction in Indonesia before and after the Asian financial crisis. Bulletin of Indonesian Economic Studies, 48 (2), 209-227. https://doi.org/10.1080/00074918.2012.694155

Tansel, C. B. (2019). Reproducing Authoritarian Neoliberalism İn Turkey: Urban Governance and State Restructuring İn The Shadow of Executive Centralization. Globalizations, 16 (3), 320-335. https://doi.org/10.1080/14747731.2018.1502494

Terin, M., Aksoy, A., \& Güler, İ. O. (2013). Tarımsal Büyümeye Etki Eden Ekonomik Faktörlerin Belirlenmesi Üzerine Bir Çalışma. Iğdır Üniversitesi Fen Bilimleri Enstitüsü Dergisi, 3 (3), 41-50.

https://www.tarim.com.tr/upload/haberler/Portakal\%20Tar\%C4\%B1m\%20\%C3\%9Cr \%C3\%BCnleri\%20Piyasa\%20Raporu\%202020\%20ocak.pdf.

Uyan, M. (2017). Optimal site selection for solar power plants using multi-criteria evaluation: A case study from the Ayranci Region in Karaman, Turkey. Clean Technologies and Environmental Policy, 19 (9), 2231-2244. https://doi.org/10.1007/s10098-017-1405-2

UNDP. (2021). Covid-19 Rapid Impact Assessment on the Agri-Food Sector and Rural Areas in Turkey. UNDP-FAO-IFAD Publications. April, 2021

WB. (2020). Pandemic, Recession: The Global Economy in Crisis. World Bank Global Economic Prospects. June, 2020. https://doi.org/10.1596/978-1-4648-1553-9

Yeni, O., \& Teoman, Ö. (2020). The Agriculture-Environment Relationship and Environment-based Agricultural Support Instruments in Turkey. European Review, 125. https://doi.org/10.1017/S1062798720001015

Yesilnacar, M. I., \& Cetin, H. (2005). Site selection for hazardous wastes: a case study from the GAP area, Turkey. Engineering Geology, 81 (4), 371-388. https://doi.org/10.1016/j.enggeo.2005.07.012 